\title{
Characterisation of The WOODY AsSemblages of Zululand COASTAL THORNVELD ALONG THE NSELENI RIVER
}

\author{
JANNIE P. VAN DER LINDEN \\ ${ }^{1}$ Department of Botany \\ University of Zululand \\ South Africa \\ FRANCES SIEBERT \\ ${ }^{2}$ School of Environmental Sciences and Development \\ North-West University \\ South Africa \\ STEFAN J. SIEBERT ${ }^{2}$ \\ DAAN P. FERREIRA ${ }^{1}$ \\ GEORGE J. BREDENKAMP \\ Department of Botany \\ University of Pretoria \\ South Africa \\ Correspondence to: Stefan J. Siebert \\ e-mail: stefan.siebert@nwu.ac.za
}

Postal Address: School of Environmental Sicences and Development, North-West University, Private Bag X6001, Potchefstroom 2520

\begin{abstract}
A classification of the woody component of the riparian vegetation of Zululand coastal thornveld is analysed using the height classes of different woody species as an indication of age. A total of 43 randomly stratified plots was selected using aerial photographs to include all the different plant communities in this rare and endemic vegetation type. A floristic survey of the woody component was conducted within each sample plot. Species data recorded included tree cover and tree richness. Environmental data recorded included altitude, soil type, soil chemistry, aspect and slope. The data set was analysed with TWINSPAN and four woody-plant assemblages were identified. An ordination using CANOCO was applied to examine the relationships between species distribution and associated environmental gradients. Changes in the species composition of woody assemblages occurred along an environmental gradient determined by soil properties and past land use.
\end{abstract}

Keywords: bush encroachment, forest, grassland, height classes, savanna

Aerial photographs (Fig. 1) belonging to the Owen Sitole College of Agriculture (OSCA) provide evidence that vegetation change, especially a rapid increase in woody vegetation (bush encroachment), took place after the fencing of the farm in the early 1960s (Van der Linden, 2004). Undocumented management practices altered the natural succession of the area. This included the removal of woodland and the uncontrolled bush encroachment of grassland by indigenous microphyllous species and the alien invasive Psidium guajava during the early 1980s. During the 1990s, the area was further invaded by alien species, such as Chromolaena odorata, Lantana camara, Melia azedarach and Schinus terebinthifolius (Van der Linden, 2004). Recent studies in tropical areas confirm that land-use change and subsequent plant invasions produce new vegetation assemblages. This leads to long-term changes in community structure, species composition and successional trajectory (Brown, Scatena \& Gurevitch, 2006).

From a classification and description of the vegetation at OSCA (Van der Linden, Siebert, Siebert, Ferreira \& Bredenkamp, 2005), it became clear that bush encroachment and alien invasion influenced natural species composition. This was especially noticeable along the drainage lines and riverine areas. To investigate these changes in the riparian zone of the study area, it was important to consider different successional trends that might have taken place through time. The occurrence of bush encroachment and the spread of woody species are regarded as important indicators of the transition from grassland to thornveld (O'Connor \& Crow, 2000). Climate change is now also recognised as a major co-driving force of bush encroachment in southern Africa (Ringrose, Chipanshi, Matheson, Chanda, Motoma, Magole \& Jellema, 2002). In combination with typical human-induced stresses (such as over-grazing, waste-dumping and alien invasive species [Rapport \& Whitford, 1999]), this led to increased encroachment at OSCA in the 1990s.

As OSCA has a complex topography and steep altitudinal gradients, it was regarded as an ideal study area in which to investigate the possible relationships between riparian vegetation and environmental factors, such as slope, soil properties, aspect and altitude. Furthermore, the disturbance history - albeit poorly documented - of the past 70 years provided a platform to initiate studies on vegetation change. The aims of this study were therefore to classify the woody component, to establish the current distribution pattern of woody-plant assemblages and to relate the current distribution of species to past disturbance regimes. This study provides a quantitative assessment of the dynamic grassland-thornveld ecotone of riparian areas in coastal Zululand and enables the documentation of the different seral stages of succession across the environmental gradients of the study area.

\section{STUDY AREA}

OSCA is situated $12,5 \mathrm{~km}$ north of Empangeni in Zululand on the old Mtubatuba road (Fig. 2). The 672 ha farm covers, 

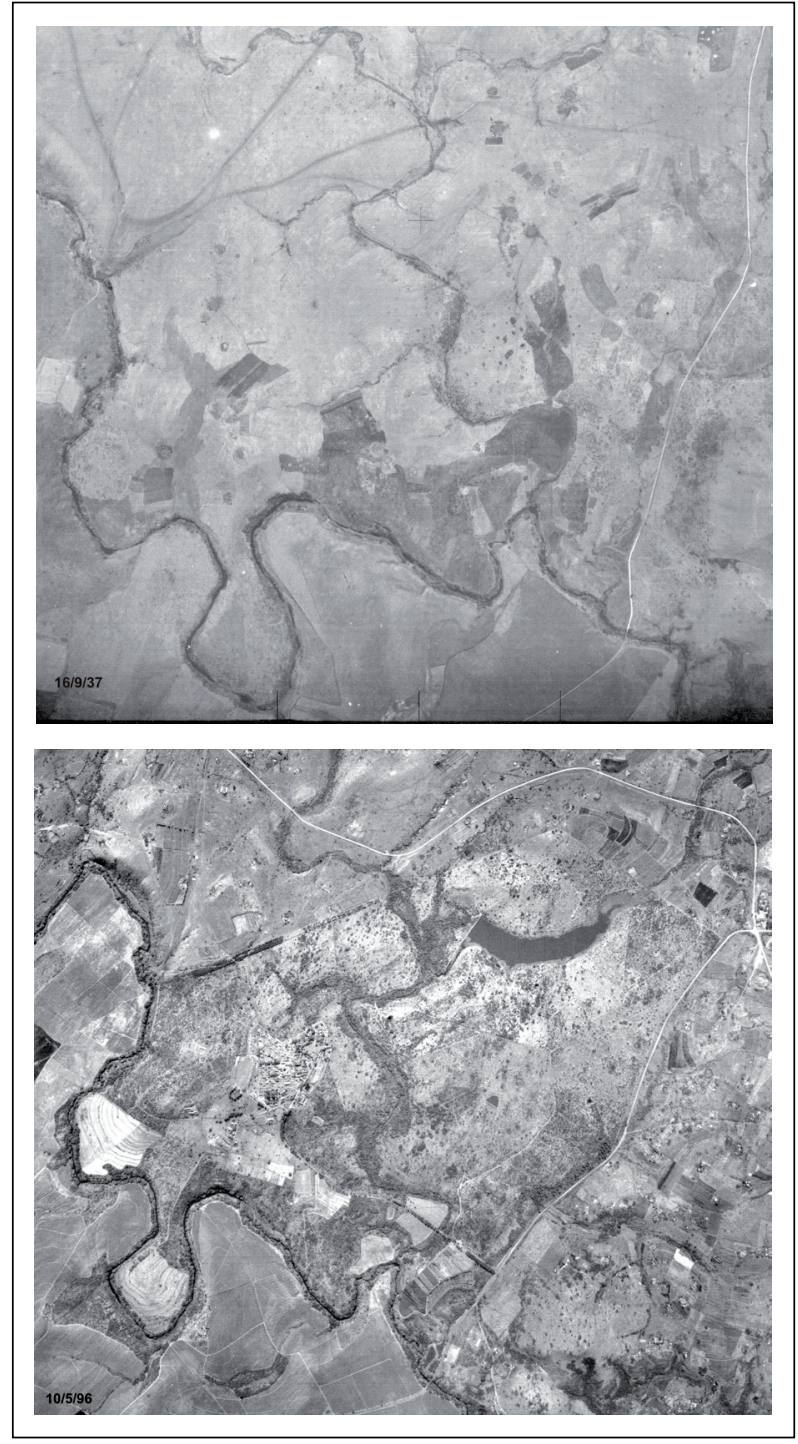

FIGURE 1

Aerial photographs of the farm of the Owen Sitole College of Agriculture during (a) 1937 and (b) 1996

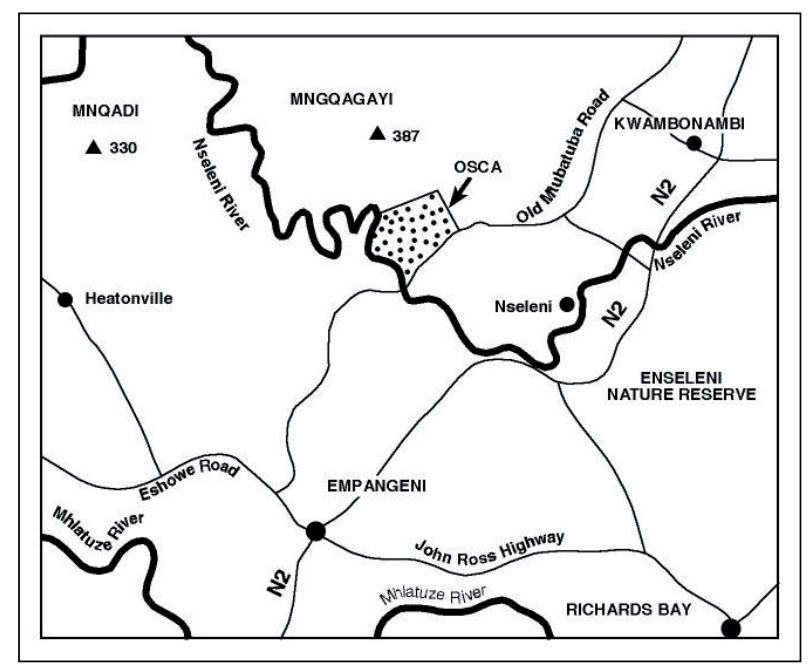

FIGURE 2

FIGURE 2
Locality of the Owen Sitole College of Agriculture in Zululand, KwaZulu-Natal

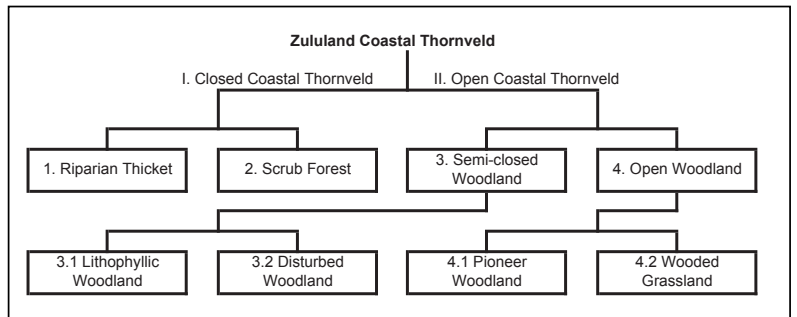

FIGURE 3

Dendrogram based on TWINSPAN divisions depicting the floristic relationships between the different woody assemblages of Zululand coastal thornveld

on average, $3,2 \mathrm{~km}$ from east to west and $2,2 \mathrm{~km}$ from north to south. The area extends from latitudes $28^{\circ} 34^{\prime} 28^{\prime \prime}$ to $28^{\circ} 34^{\prime} 20^{\prime \prime} \mathrm{S}$ and from longitudes $31^{\circ} 57^{\prime} 31^{\prime \prime}$ to $31^{\circ} 57^{\prime} 22^{\prime \prime}$ E. The eastern boundary is formed by the old Empangeni-Mtubatuba road and the south-western boundary by the Nseleni River (Van der Linden et al., 2005).

The elevation of the farm varies from $23 \mathrm{~m}$ above sea level at the lowest point in the valley - the Nseleni River - to $120 \mathrm{~m}$ on the hills in the north-western portion of the farm. The landscape comprises a series of undulating hills sloping down to the lowlying flood plain of the Nseleni River. A tributary, the Cwaka River, flows from the north into the Nseleni River, dividing the farm into two approximately equal parts.

The mean annual rainfall for OSCA is $1022 \mathrm{~mm}$ (Agromet, 2002), of which a third falls in mid to late summer (from January to March). Rain falls throughout the year, although drier spells occur during the winter months. Mean daily temperatures range from $19{ }^{\circ} \mathrm{C}$ in winter to $33{ }^{\circ} \mathrm{C}$ in summer. The mean annual temperature is $26^{\circ} \mathrm{C}$ (Agromet, 2002).

The study area is underlain by the Karoo sequence, namely the volcanic basalts of the Letaba formation of the Lebombo group (Visser, Coertze \& Walraven, 1989). The flood plains and river terraces are underlain by alluvium. Nine different soil forms occur in the study area, of which Mayo is the most dominant (Van der Linden, 2004).

Land use in the surrounding areas comprises subsistence farming, timber plantations and sugar-cane fields. The consequence of these practices is that natural vegetation remains only in small, isolated patches of the landscape. Within OSCA, numerous patches of natural vegetation remain, hence making it an area of conservation priority (Van der Linden $e t$ al., 2005).

Camp (1977) places the study area in the Moist Coast Forest, Thorn and Palmveld, and the Moist Zululand Thornveld bioresource units. Acocks (1988) places OSCA under the Coastalforest and Thornveld veld type. Granger, Bredenkamp and Van Rooyen (1996) place the study area under the Coastal Bushveld-grassland vegetation type. More recently, Mucina and Rutherford (2006) have placed it in the Zululand Coastalthornveld vegetation unit, which is endemic to northern KwaZulu-Natal.

\section{Disturbance history}

Aerial photographs clearly indicate whether the woody component of the vegetation in an area has increased during a given period (Breebaart, O'Connor, Morris \& Rushworth, 2001). A comparison of aerial photographs of OSCA taken in 1937 and 1996 (Fig. 1) reveals a considerable increase in woody vegetation in the study area (Van der Linden, 2004).

During the 1930s, the study area (OSCA) was predominantly grassland. Prior to and during the 1930s (according to current 


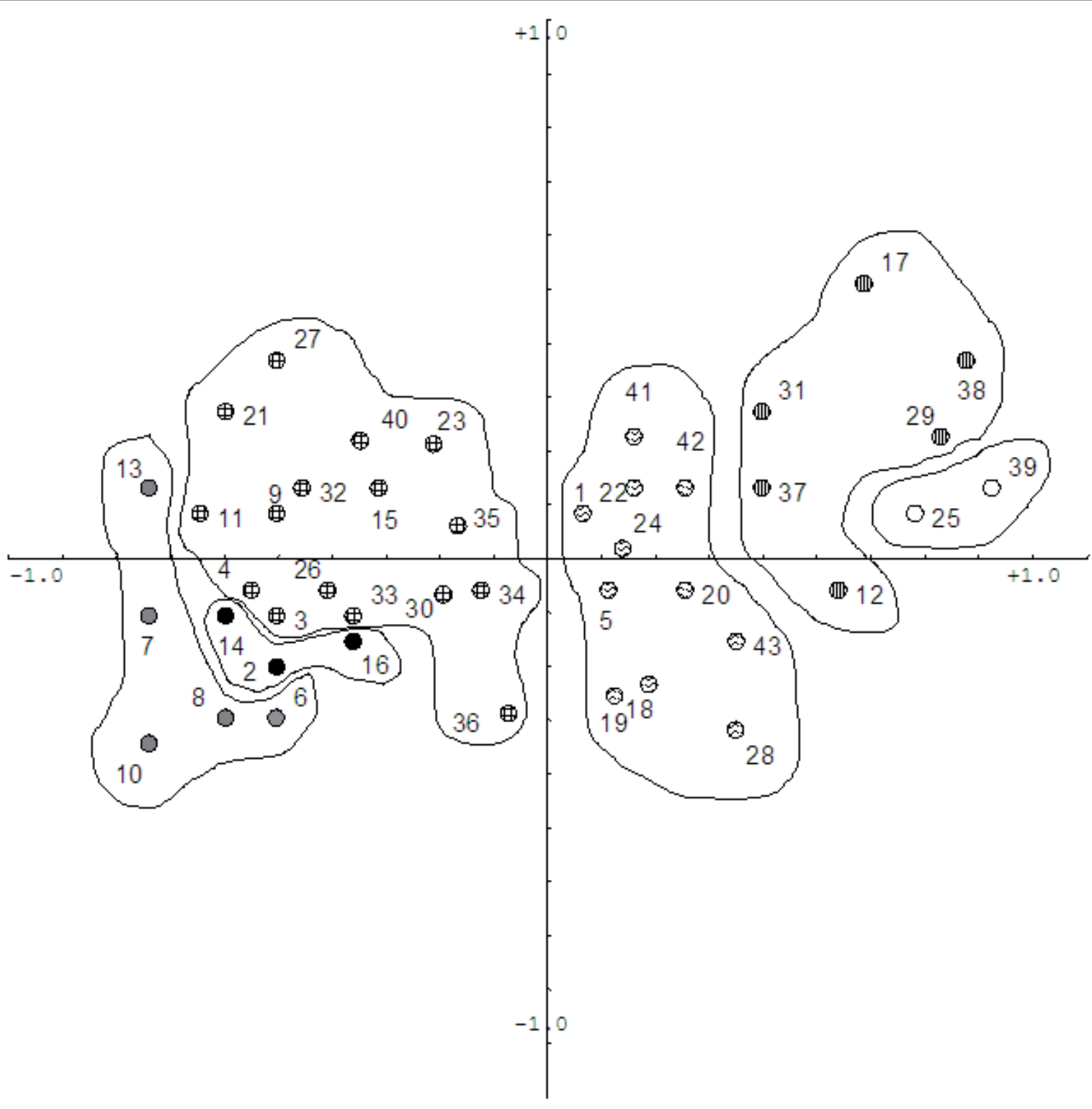

Drier, shallower soils further from drainage lines -------Deeper soil close to drainage lines

Commiphora harveyi-Cussonia zuluensis Riparian Thicket

Trimeria grandiflora-Acacia robusta Scrub Forest

Euclea undulata-Rhus rehmanniana Lithophyllic Woodland

Euclea racemosa-Schinus terebinthifolius Disturbed Woodland

Acacia karroo-Acacia nilotica Pioneer Woodland

Acacia karroo-Lippia javanica Wooded Grassland

FIGURE 4

Standardised PCA of all plots depicting a gradient from areas with deep soils near drainage lines and riparian areas to higher-lying areas further away with shallower soils

hypotheses), woody plants were probably suppressed by extensive fires, over-grazing by goats or removal for firewood (Van der Linden et al., 2005).

After 1940, changes in land use strongly influenced the vegetation of the area. During the 1940s and '50s, farming practices changed from cattle farming to mixed farming to include crop cultivation, resulting in extensive ploughed fields where woody vegetation was continuously removed (Van der Linden, 2004). These practices continued until the early 1960s, when government established an agricultural training centre (then known as the Mangosuthu College) and fenced the farm.
Between 1960 and 1990, different alternating management regimes on the farm probably resulted in various changes in vegetation composition and structure. Unfortunately, no detailed farming practices or disturbance history was recorded for this period, hence no possible drivers of vegetation change can be singled out.

At the beginning of 1991, the Mangosuthu College closed down and government tasked the Cedara Agricultural College with managing the farm. In 1995, the Department of Technology Development and Training inherited the farm and, at the beginning of 1996, OSCA was opened. Since then, a lack of appropriate funds and farm management has resulted in only 
TABLE 1 Zululand coastal thornveld

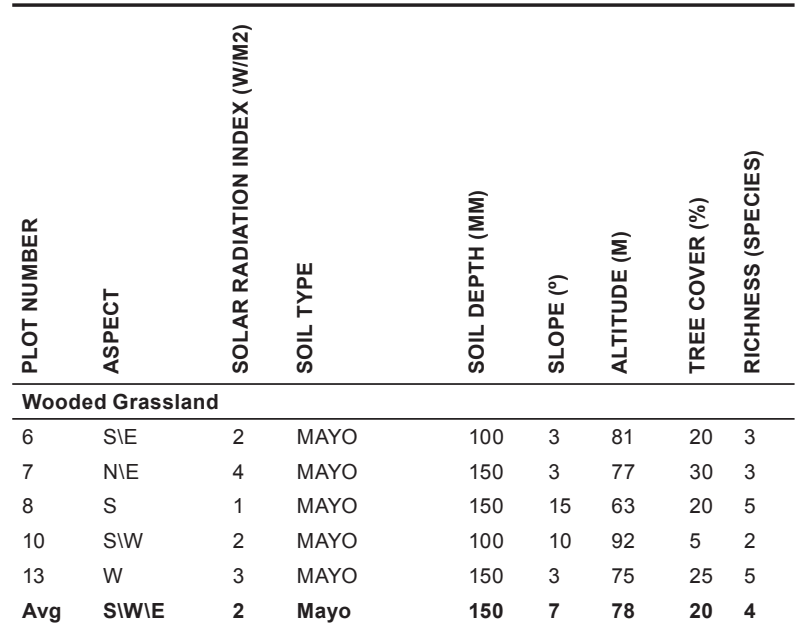

Pioneer Woodland

$\begin{array}{lllllllll}2 & \text { E } & 3 & \text { MAYO } & 200 & 8 & 101 & 40 & 7 \\ 14 & \text { NIE } & 4 & \text { MAYO } & 100 & 3 & 84 & 25 & 8 \\ 16 & \text { S } & 1 & \text { MAYO } & 150 & 10 & 96 & 15 & 5 \\ \text { Avg } & \text { E } & \mathbf{3} & \text { Mayo } & \mathbf{1 5 0} & \mathbf{7} & \mathbf{9 4} & \mathbf{2 7} & \mathbf{7}\end{array}$

Disturbed Woodland

\begin{tabular}{lllllllll}
\hline 3 & SIW & 2 & MAYO & 200 & 5 & 110 & 40 & 10 \\
4 & SIE & 2 & MAYO & 200 & 10 & 70 & 35 & 12 \\
9 & SIE & 2 & MAYO & 200 & 13 & 109 & 40 & 13 \\
11 & E & 3 & RENSBURG & 200 & 3 & 50 & 45 & 21 \\
15 & NIE & 5 & MAYO & 150 & 3 & 69 & 35 & 13 \\
21 & W & 3 & MAYO & 250 & 8 & 65 & 60 & 8 \\
23 & N & 5 & GLENROSA & 250 & 13 & 87 & 40 & 16 \\
26 & E & 3 & SHORTLANDS & 150 & 3 & 60 & 35 & 12 \\
27 & S & 1 & MAYO & 200 & 5 & 67 & 45 & 18 \\
30 & W & 3 & GLENROSA & 200 & 3 & 71 & 75 & 8 \\
32 & E & 3 & GLENROSA & 300 & 5 & 74 & 50 & 12 \\
33 & NIE & 4 & INHOEK & 300 & 6 & 48 & 50 & 12 \\
34 & E & 3 & MAYO & 200 & 10 & 71 & 40 & 14 \\
35 & S & 1 & MAYO & 200 & 15 & 68 & 35 & 13 \\
36 & NIE & 4 & MAYO & 200 & 8 & 90 & 35 & 13 \\
40 & W & 3 & MAYO & 300 & 13 & 34 & 40 & 15 \\
Avg & SIE & $\mathbf{3}$ & Mayo, Glen & $\mathbf{2 0 0}$ & $\mathbf{8}$ & $\mathbf{7 1}$ & $\mathbf{4 4}$ & $\mathbf{1 3}$ \\
Lithophyllic Woodland & & & & & & \\
\hline 1 & E & 3 & INHOEK & 250 & 3 & 79 & 75 & 16 \\
5 & NIE & 4 & MAYO & 200 & 3 & 81 & 75 & 16 \\
18 & S & 1 & MAYO & 100 & 18 & 39 & 35 & 17 \\
19 & SIW & 2 & INHOEK & 200 & 3 & 60 & 35 & 17 \\
20 & W & 3 & MAYO & 100 & 15 & 74 & 35 & 17 \\
22 & NIW & 4 & MAYO & 100 & 10 & 88 & 70 & 11 \\
24 & SIE & 2 & MAYO & 100 & 8 & 65 & 20 & 15 \\
28 & N & 5 & MAYO & 150 & 5 & 74 & 35 & 18 \\
41 & SIW & 2 & MAYO & 100 & 15 & 118 & 15 & 9 \\
42 & W & 3 & MAYO & 100 & 20 & 56 & 35 & 17 \\
Avg & SIW & $\mathbf{3}$ & Mayo, Inho & $\mathbf{1 0 0}$ & $\mathbf{1 0}$ & 73 & $\mathbf{4 3}$ & 15
\end{tabular}

\begin{tabular}{|c|c|c|c|c|c|c|c|c|}
\hline \multicolumn{9}{|c|}{ Scrub Forest } \\
\hline 12 & NIW & 4 & MAYO & 300 & 18 & 62 & 90 & 18 \\
\hline 17 & $S$ & 1 & INHOEK & 800 & 5 & 47 & 90 & 21 \\
\hline 29 & w & 3 & OAKLEAF & 800 & 3 & 47 & 90 & 15 \\
\hline 31 & siw & 2 & SHORTLANDS & 800 & 3 & 96 & 95 & 17 \\
\hline 37 & w & 3 & MAYO & 300 & 5 & 48 & 95 & 12 \\
\hline 38 & SIE & 2 & OAKLEAF & 800 & 3 & 45 & 95 & 16 \\
\hline 43 & SIW & 2 & INHOEK & 400 & 8 & 41 & 85 & 13 \\
\hline Avg & siw & 3 & Mayo, Oakl & 800 & 6 & 55 & 91 & 16 \\
\hline \multicolumn{9}{|c|}{ Riparian Thicket } \\
\hline 25 & $\mathrm{~N}$ & 5 & GLENROSA & 400 & 20 & 67 & 95 & 19 \\
\hline 39 & $E$ & 3 & GLENROSA & 300 & 23 & 88 & 95 & 21 \\
\hline Avg & NIE & 4 & Glen & 350 & 22 & 78 & 95 & 20 \\
\hline
\end{tabular}

certain areas being utilised, while uncontrolled fires occur annually.

\section{METHODS}

The entire area of the OSCA farm was stratified into relatively homogeneous physiographic-physiognomic units using recent 1:50 000 stereo aerial photographs (Fig. 1). Forty-three sample plots were randomly located within these known units (Van der Linden et al., 2005) to ensure that site selection was objective. A grid of coordinates was placed on a topographic map and pairs of random numbers were drawn to select each sample plot. These points were then transferred to an aerial photograph to locate the exact positions of the plots. The plot size for the woody-plant survey was fixed at $20 \times 20 \mathrm{~m}$, based on previous work conducted on vegetation with a similar structure (Siebert, Matthee \& Van Wyk, 2003).

To quantify bush encroachment at OSCA, the woody species were divided into size classes (Brown \& Bredenkamp, 2004) and it was assumed that different size classes represent different age categories. The woody species were divided into three groups, namely microphyllous, broadleaved and invasive-alien. In the structural assessment of the three groups, all species were divided into three height classes, namely short $(0,5$ to $1,5 \mathrm{~m})$, medium $(1,5$ to $3 \mathrm{~m})$ and tall $(>3 \mathrm{~m})$, based on Breebaart et al. (2001). The woody cover and density of individuals in each height class within each group were determined for each sample plot. Density was expressed as individuals per hectare and woody cover as an estimate percentage cover of the plot (Van der Linden et al., 2005).

Cover-abundance data of woody species were analysed with two-way indicator-species analysis (TWINSPAN) (Hill, 1979) to obtain a classification of woody-plant assemblages. BraunBlanquet procedures (Westhoff \& Van der Maarel, 1978) were sparingly applied to refine the classification. Two primary ordination techniques were used in this study to detect different types of underlying structures. Principal-components analysis (PCA) relates to a linear response model in which the abundance of any species or environmental characteristic either increases or decreases with the value of each of the environmental variables. PCA was independently applied to the data set to determine the correlation between environmental variables - specifically soil - and floristic data (Ter Braak \& Smilauer, 2002).

Floristic compositional gradients were independently investigated using correspondence analysis (CA) (Ter Braak \& Smilauer, 2002). CA is related to a unimodel response model which accepts that any species occurs in a limited range of values for any given environmental variable. Canonicalcorrespondence analysis (CCA) was used in a constrained ordination approach to determine the direct influence of environmental variables (e.g. aspect, slope, soil properties, elevation) on the distribution of the woody plant communities (Ter Braak \& Smilauer, 2002). Disturbance factors such as fire and grazing were recorded but not entered for data analysis.

Soil samples were analysed with the rapid procedures described by Hunter (1975) and Farina (1981). Soil classification was done according to the Soil Classification Work Group (1977). Solar radiation was measured with an LI-COR pyranometer (Michalsky, Perez, Harrison \& Le Baron, 1991).

\section{RESULTS AND DISCUSSION}

\section{Classification of woody-plant assemblages}

This paper does not investigate the patterns of distribution for the total floristics of a plant community but focuses on woodyplant species assemblages only. The term "species assemblage" 
TWINSPAN classification of the woody species assemblages

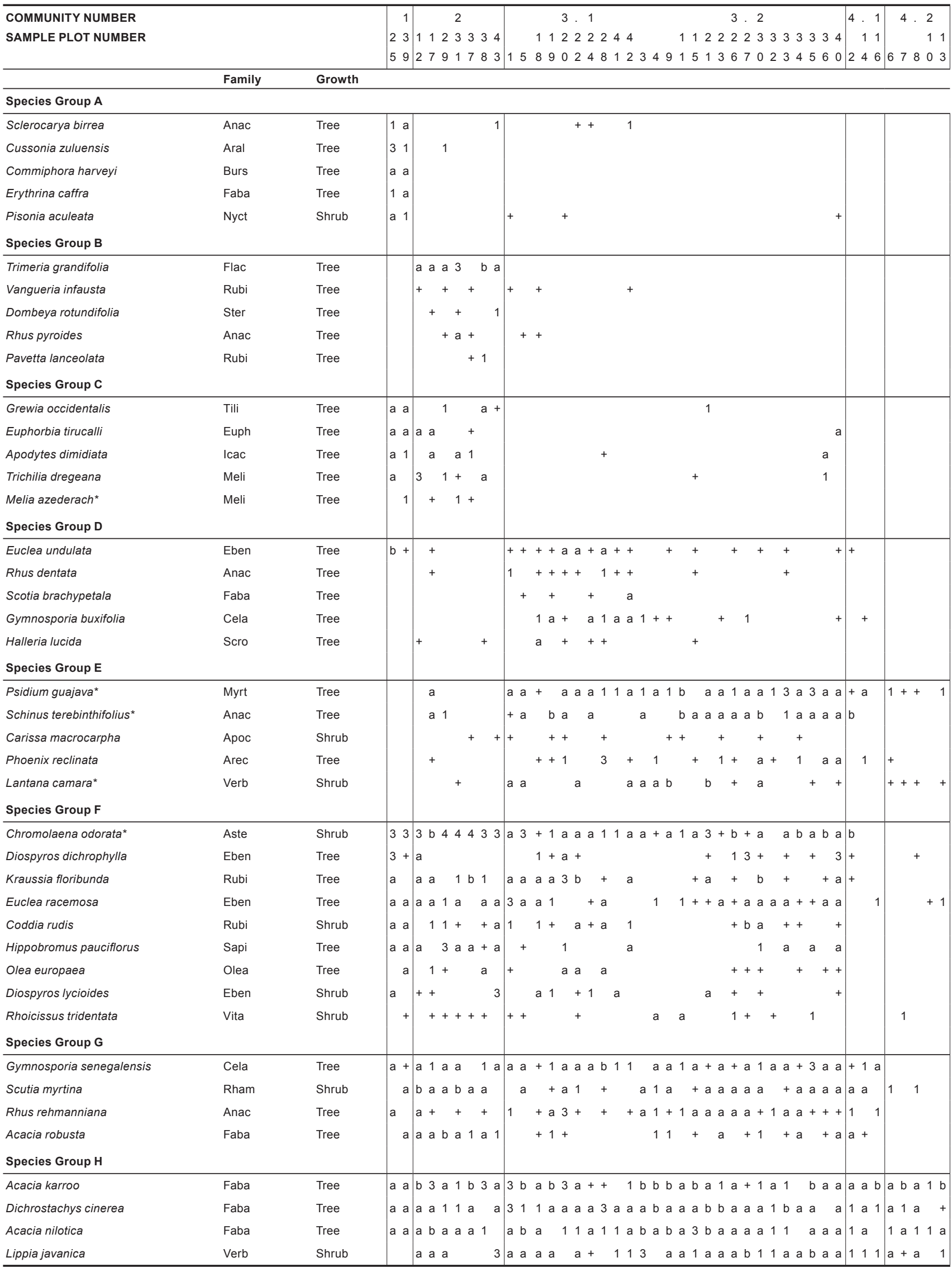


TABLE 3

Soil chemical attributes at 150,300 and $600 \mathrm{~mm}$ depth for each of the woody species assemblages

\begin{tabular}{|c|c|c|c|c|c|c|c|c|c|c|c|}
\hline & Sample depth & $\mathrm{Ca}$ & $\mathrm{Mg}$ & $\mathbf{K}$ & $\mathbf{P}$ & $\mathrm{Zn}$ & $\mathrm{Mn}$ & OrC & Clay & Cat & $\mathrm{pH}$ \\
\hline & & $(\mathrm{ppm})$ & (ppm) & $(\mathrm{ppm})$ & $\%$ & $\%$ & $\%$ & $\%$ & $\%$ & meq $/ 100 \mathrm{~g}$ & \\
\hline \multirow[t]{4}{*}{ Wooded Grassland } & $150 \mathrm{~mm}$ & 2932.4 & 1398.4 & 91.2 & 1.2 & 0.6 & 7.8 & 4.8 & 63.4 & 26.5 & 5.0 \\
\hline & $300 \mathrm{~mm}$ & 2934.2 & 1702.8 & 93.2 & 2.0 & 0.7 & 4.6 & 4.0 & 63.0 & 29.0 & 5.1 \\
\hline & $600 \mathrm{~mm}$ & 3655.8 & 2157.8 & 75.2 & 1.2 & 0.7 & 3.4 & 2.2 & 67.0 & 36.3 & 5.5 \\
\hline & Mean & 3174.1 & 1753.0 & 86.5 & 1.5 & 0.7 & 5.3 & 3.7 & 64.5 & 30.6 & 5.2 \\
\hline \multirow[t]{4}{*}{ Pioneer Woodland } & $150 \mathrm{~mm}$ & 1486.5 & 899.0 & 225.5 & 2.0 & 0.8 & 9.5 & 4.3 & 53.0 & 15.3 & 5.1 \\
\hline & $300 \mathrm{~mm}$ & 2317.7 & 1650.7 & 94.3 & 1.0 & 0.7 & 4.7 & 3.4 & 68.7 & 25.5 & 5.2 \\
\hline & $600 \mathrm{~mm}$ & 1839.8 & 1656.0 & 136.2 & 1.3 & 0.6 & 6.7 & 3.1 & 60.2 & 21.8 & 5.2 \\
\hline & Mean & 1881.3 & 1401.9 & 152.0 & 1.4 & 0.7 & 6.9 & 3.6 & 60.6 & 20.9 & 5.2 \\
\hline \multirow[t]{4}{*}{ Disturbed Woodland } & $150 \mathrm{~mm}$ & 3606.9 & 1512.6 & 177.3 & 1.4 & 0.7 & 8.1 & 3.7 & 62.8 & 28.9 & 5.0 \\
\hline & $300 \mathrm{~mm}$ & 3889.8 & 1704.3 & 132.0 & 1.1 & 0.6 & 5.7 & 2.7 & 62.3 & 33.9 & 5.0 \\
\hline & $600 \mathrm{~mm}$ & 4179.6 & 1835.0 & 106.9 & 1.1 & 0.5 & 4.0 & 2.6 & 61.1 & 36.5 & 5.2 \\
\hline & Mean & 3892.1 & 1684.0 & 138.7 & 1.2 & 0.6 & 5.9 & 3.0 & 62.1 & 33.1 & 5.1 \\
\hline \multirow[t]{4}{*}{ Lithophyllic Woodland } & $150 \mathrm{~mm}$ & 3511.2 & 1406.0 & 78.1 & 1.3 & 0.9 & 7.1 & 4.5 & 57.1 & 29.4 & 4.9 \\
\hline & $300 \mathrm{~mm}$ & 4223.2 & 1499.5 & 89.4 & 1.1 & 0.7 & 4.9 & 4.5 & 62.4 & 34.6 & 4.7 \\
\hline & $600 \mathrm{~mm}$ & 4657.0 & 1777.4 & 55.8 & 1.0 & 0.8 & 5.3 & 3.6 & 56.4 & 38.1 & 5.3 \\
\hline & Mean & 4130.5 & 1561.0 & 74.4 & 1.1 & 0.8 & 5.8 & 4.2 & 58.6 & 34.0 & 5.0 \\
\hline \multirow[t]{4}{*}{ Scrub Forest } & $150 \mathrm{~mm}$ & 2356.6 & 931.4 & 253.9 & 4.3 & 0.8 & 24.4 & 3.5 & 50.7 & 27.2 & 5.0 \\
\hline & $300 \mathrm{~mm}$ & 2336.7 & 1054.1 & 217.1 & 3.9 & 0.8 & 15.3 & 3.3 & 52.0 & 21.1 & 5.0 \\
\hline & $600 \mathrm{~mm}$ & 2174.0 & 1119.6 & 167.7 & 2.6 & 0.5 & 9.9 & 2.4 & 53.6 & 20.6 & 5.2 \\
\hline & Mean & 2289.1 & 1035.0 & 212.9 & 3.6 & 0.7 & 16.5 & 3.1 & 52.1 & 23.0 & 5.0 \\
\hline \multirow[t]{4}{*}{ Riparian Thicket } & $150 \mathrm{~mm}$ & 4310.0 & 1655.5 & 81.0 & 1.0 & 0.7 & 12.0 & 2.4 & 66.0 & 35.5 & 4.9 \\
\hline & $300 \mathrm{~mm}$ & 5183.0 & 1915.5 & 68.0 & 1.0 & 0.7 & 4.5 & 2.8 & 60.0 & 41.9 & 4.7 \\
\hline & $600 \mathrm{~mm}$ & 4872.5 & 2030.5 & 68.5 & 1.0 & 0.5 & 4.0 & 1.4 & 60.0 & 41.3 & 4.9 \\
\hline & Mean & 4788.5 & 1867.2 & 72.5 & 1.0 & 0.6 & 6.8 & 2.2 & 62.0 & 39.6 & 4.8 \\
\hline
\end{tabular}

OrC = organic carbon; Cat $=$ exchangeable cations

describes the collection of any set of species making up a cooccurring community of organisms in a given habitat.

The woody vegetation of the study area is generally characterised by the presence of microphyllous species (thornveld) (Van der Linden et al., 2005). The most dominant plant family of the study area is the Fabaceae. Other well-represented families include the Anacardiaceae, Ebenaceae and Rubiaceae. Forty-two taxa of woody species were recorded, of which five are declared invasive aliens.

The TWINSPAN procedure divides the woody vegetation of OSCA into two major groups of woody-species assemblages, namely Acacia karroo-Dichrostachys cinerea open coastal thornveld and Acacia karroo-Hippobromus pauciflorus closed coastal thornveld (Fig. 3). A standardised PCA of all sites supports this classification, as it represents a gradient of closed coastal-thornveld assemblages of low-lying, undisturbed, nutrient-rich, deep loam soils near drainage lines and riparian zones to open coastal-thornveld assemblages of higher-lying, disturbed areas further away from drainage lines on shallower, less nutrient-rich clay soils (Fig. 4).

Four woody-plant assemblages were identified from the TWINSPAN application (Table 1; Fig. 3). These assemblages can, to some extent, be related to the plant communities described for OSCA (Van der Linden et al., 2005). Open coastal thornveld, however, shows weaker relationships with these communities, as grassland at OSCA has poor woody-plant species-richness and classification of the grassland communities was based mainly on the herbaceous layer. Habitat features of these communities and sub-communities are summarised in Table 2 and soil chemistry is given in Table 3 .

The woody-plant assemblages are classified as follows:

I. Acacia karroo-Hippobromus pauciflorus closed coastal thornveld
1. Commiphora harveyi-Cussonia zuluensis riparian thicket 2. Trimeria grandiflora-Acacia robusta scrub forest

II. Acacia karroo-Dichrostachys cinerea open coastal thornveld

3. Phoenix reclinata-Gymnosporia buxifolia semi-closed woodland

3.1 Euclea undulata-Rhus rehmanniana lithophyllic woodland

3.2 Euclea racemosa-Schinus terebinthifolius disturbed woodland

4. Acacia nilotica-Dichrostachys cinerea open woodland

4.1 Acacia nilotica-Acacia karroo pioneer woodland

4.2 Acacia karroo-Lippia javanica wooded grassland

\section{Description of woody-plant assemblages}

I. Acacia karroo-Hippobromus pauciflorus closed coastal thornveld

= Acacia karroo-Hippobromus pauciflorus closed coastal thornveld (Van der Linden et al., 2005)

This first of the two major woody assemblages is found mainly near drainage lines in deeper soils and is associated with little or no disturbance (Table 2). Vegetation is characterised by a dominance of trees in the $>3 \mathrm{~m}$ height class (Fig. 5). The number of broadleaved species for this species assemblage is the highest for all three height classes. The presence of microphyllous species, such as Acacia karroo, A. nilotica and Dichrostachys cinerea (species group H; Table 1), are typical of thornveld (Fig. 6a, b). The assemblage is also characterised by high numbers of alien species, especially in the $>3 \mathrm{~m}$ height class (Fig. 6c).

Diagnostic species are Apodytes dimidiata, Euphorbia tirucalli, Grewia occidentalis and Trichilia dregeana (species group C; Table 1). The seedling survival of microphyllous Acacia karroo, A. nilotica and Dichrostachys cinerea species is low in the 0,5 to $1,5 \mathrm{~m}$ size class, declining rapidly in the higher size classes due to intolerance to the shade created by clumps of large trees (Fig. 6b). 


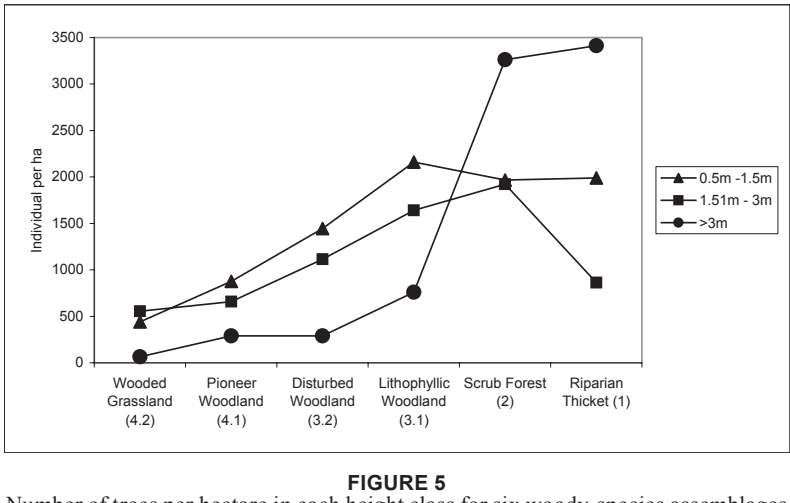

Number of trees per hectare in each height class for six woody-species assemblages of Zululand coastal thornveld

The closed coastal thornveld is divided into two woody assemblages, which are described below.

1. Commiphora harveyi-Cussonia zuluensis riparian thicket

= Commiphora harveyi-Cussonia zuluensis riparian thicket (Van der Linden et al., 2005)

This assemblage occurs on steep slopes (of $>20^{\circ}$ ) and is situated nearest to the Nseleni River. It is characterised by underlying rock and has the study area's deepest soils, the Glenrosa soil form (Table 2). Its habitat receives the highest average solar radiation (Table 2). No cultivation, fire or grazing occurred extensively in this habitat in the past due to its steep slopes. In contrast to the scrub forest (2), the associated soil contains lower $\mathrm{K}, \mathrm{P}$ and $\mathrm{Mn}$ values but higher $\mathrm{Ca}$ and $\mathrm{Mg}$ values (Table 3 ).

Diagnostic species of this assemblage are Commiphora harveyi, Cussonia zuluensis, Erythrina caffra, Pisonia aculeata (a climber) and Sclerocarya birrea (species group A; Table 1). The plant community associated with the woody assemblage is speciesrich when compared to the scrub forest (Van der Linden et al., 2005). Although Acacia karroo, A. nilotica and Dichrostachys cinerea are prevalent, broadleaf plant species are typical of this assemblage. Other prominent broadleaf tree species include Apodytes dimidiata, Euphorbia tirucalli and Grewia occidentalis (species group C; Table 1). Another important characteristic of this community is the dense stand of Chromolaena odorata (species group F; Table 1), especially in the higher $(>3 \mathrm{~m}$ ) size class, where it tends to smother other plant species. The abundance of broadleaf species in the lowest size class indicates a high rate of recruitment but these numbers decrease rapidly with age, until only a few individuals survive in the $>3$ m class in comparison with the high numbers of seedlings (Fig. 6a).

\section{Trimeria grandiflora-Acacia robusta scrub forest}

= Asparagus falcatus-Trimeria grandifolia scrub forest (Van der Linden et al., 2005)

This assemblage occurs in the low lying areas (of $55 \mathrm{~m}$ ) that are not steeply sloped $\left(6^{\circ}\right)$. Habitat is characterised by many different soil types, with a soil depth ranging from 300 to 800 $\mathrm{mm}$ (Table 2) and the lowest clay content in the study area. The soil, on average, contains the lowest $\mathrm{Mg}$ but the highest $\mathrm{K}, \mathrm{P}$ and $\mathrm{Mn}$ concentrations of all the habitat types (Table 3). The associated plant community occurs as secondary forest on old cultivated fields abandoned in the 1960s.

Diagnostic species are the broadleaved taxa Dombeya rotundifolia, Pavetta lanceolata, Rhus pyroides, Trimeria grandifolia and Vangueria infausta (species group B; Table 1). Due to the relatively low abundance of grasses (Van der Linden et al., 2005), no grazing or fire occurred in this habitat for a long period, which has resulted in a high density of woody vegetation (Fig. 5). The mean tree cover (of 91\%) is similar to that of the riparian thicket (of 95\%) but far exceeds that of the other four woody assemblages (Table 2).

This assemblage has the highest density of trees in the study area in the 1,51 to $3 \mathrm{~m}$ height class (Fig. 5). Densities of the microphyllous species Acacia karroo, A. nilotica, A. robusta and Dichrostachys cinerea are at the lower levels (Fig. 6b) due to the high canopy cover. Densities of broadleaved species in the 0,5 to $1,5 \mathrm{~m}$ and 1,51 to $3 \mathrm{~m}$ classes are much higher than recorded for the riparian thicket (1), however, with a higher survival of species in the $>3 \mathrm{~m}$ height class (Fig. 6a). Chromolaena odorata is also increasing when its density in the $>3 \mathrm{~m}$ height class is considered (Fig. 6c), while density in the 0,5 to $1,5 \mathrm{~m}$ and 1,51 to $3 \mathrm{~m}$ size classes is more or less constant (Fig. 5). The high density of Chromolaena odorata in the higher (>3 m) classes could result in it smothering the woody species with time.

\section{Acacia karroo-Dichrostachys cinerea open coastal thornveld}

= Acacia karroo-Themeda triandra open coastal thornveld (Van der Linden et al., 2005)

This second of the two major woody assemblages is found in various soil types that vary in soil depth but are generally shallow (Table 2). The topography ranges from flat, higherlying areas away from drainage lines, with a higher disturbance regime in the past (through, for example, cultivation, frequent burning and, in some areas, over-grazing), to steeper, rocky areas, with less disturbance in the past (disturbance being through fire and over-grazing) due to the steepness (13 to $20^{\circ}$ ). The assemblage is characterised by an abundance of trees in the 0,5 to $1,5 \mathrm{~m}$ height class (Fig. 5).

Microphyllous species, such as Acacia robusta (species group G; Table 1), A. karroo, A. nilotica and Dichrostachys cinerea (species group H; Table 1), broadleaved species, such as Gymnosporia senegalensis, Rhus rehmanniana (species group G; Table 1) and Lippia javanica (species group H; Table 1) and invader species, such as Psidium guajava and Schinus terebinthifolius (species group E; Table 1), are diagnostic for all size classes (Fig. 6). Common broadleaved species typical of closed coastal thornveld are absent or rare and the species of invasive aliens present clearly differentiate between the two major woody assemblages.

The open coastal thornveld is divided into two woody assemblages, each comprising two sub-units.

\section{Phoenix reclinata-Gymnosporia buxifolia semi-closed woodland}

= Diheteropogon amplectens-Phoenix reclinata open woodland (Van der Linden et al., 2005)

This woody assemblage (Fig. 3) is the most widespread in the study area and occurs in a wide range of soil types and depths (from 100 to $300 \mathrm{~mm}$ ). It is found on steep, rocky slopes with shallow soils away from drainage lines to relatively flat areas with deep soils (Table 2). The steeper, rocky areas were never cultivated, they were only lightly grazed and fewer fires occurred in the past, while the flatter habitat was extensively cultivated, grazed and burnt during the 1940s and early 1950s. Although the physiognomy remains relatively homogeneous throughout the range, the shallow soils harbour a slightly different species composition to that of the previously ploughed, deeper soils. Vegetation in the deeper soils represents a seral stage that is close to the so-called "climax" state of the vegetation in the shallow soils. It can be expected that the woody assemblages in the deeper soils may develop further to reach a so-called "climax". The density of the trees has increased in this habitat since the 1960s (Van der Linden, 2004), with a particular increase in microphyllous and invader species. 

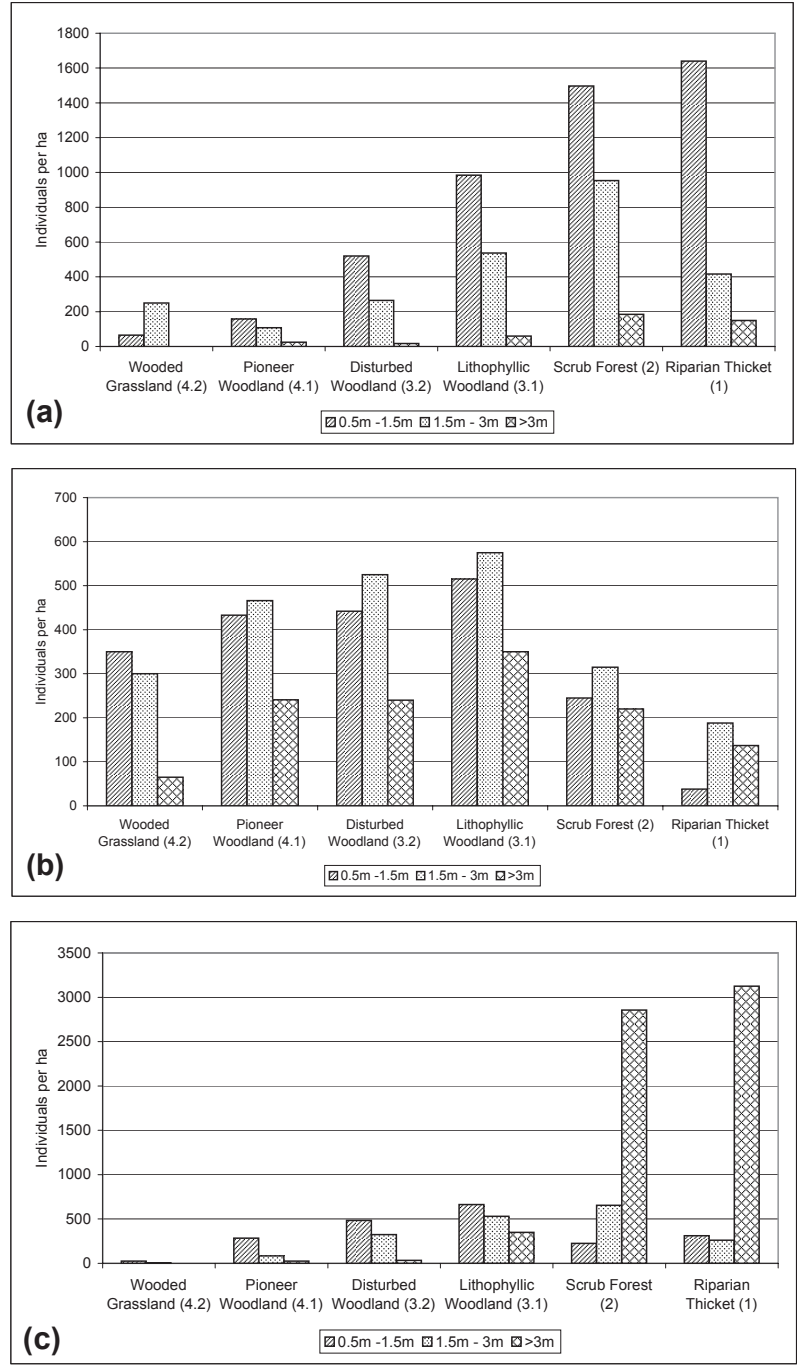

FIGURE 6

Population size structure of (a) broadleaved, (b) microphyllous and (c) alieninvasive tree species for three height classes in each woody assemblage

Some diagnostic species in this community include Gymnosporia buxifolia, Lantana camara, Phoenix reclinata, Psidium guajava and Schinus terebinthifolius (species groups D and E; Table 1).

Cultivation appears to have had a marked negative influence on species-richness and tree density (Table 2; Fig. 5) as well as canopy cover. The mean number of tree species and cover was higher in the old fields, which are close to rural communities and where most veld fires originated.

The semi-closed woodland is divided into two smaller subunits based on soil depth and rockiness.

\subsection{Euclea undulata-Rhus rehmanniana lithophyllic woodland = Trachypogon spicatus-Gymnosporia buxifolia rocky open woodland (Van der Linden et al., 2005)}

This assemblage occurs in shallow soils (with a mean depth of $140 \mathrm{~mm}$ ). Some sample plots are situated on steeper slopes with shallow rocky soils and others in flat areas (Table 2) that were cultivated before or during the early 1940s (Van der Linden, 2004). Habitat is characterised by soil with a consistently high Ca content (Table 3). The soil also has the highest organic carbon content at 300 and $600 \mathrm{~mm}$ depths. Steepness and rockiness and the occurrence of vegetation as bush clumps prevent fires and grazers from disturbing the woody assemblage.
Diagnostic species of this assemblage are Euclea undulata, Gymnosporia buxifolia, Halleria lucida, Rhus dentata and Schotia brachypetala (species group D; Table 1). The assemblage is more species-rich (Table 2) and has higher densities of trees (Fig. 6a, b) than the disturbed woodland (3.2) due to the absence of disturbance for long periods. Acacia karroo, A. nilotica, Chromolaena odorata, Dichrostachys cinerea, Gymnosporia senegalensis, Kraussia floribunda, Lippia javanica and Psidium guajava dominate the assemblage (species groups E, F, G and $\mathrm{H}$; Table 1). Although microphyllous species are the most prevalent, broadleaf tree species are typical in the lower 0,5 to 1,5 m height class (Fig. 6a). These include Coddia rudis, Diospyros dichrophylla, D. lycioides, Olea europaea and Rhus rehmanniana (species groups F and G; Table 1).

The frequent occurrence of microphyllous and broadleaf species as shrubs (Fig. 6a, b) is evidence of repeated fire and overgrazing during the late 1980s and early 1990s. The dominance of broadleaved species in the 0,5 to $1,5 \mathrm{~m}$ height class suggests that this community, as is the case with the disturbed woodland (3.2), has potential for conversion to closed woodland.

3.2 Euclea racemosa-Schinus terebinthifolius disturbed woodland

= Chloris gayana-Schinus terebinthifolius disturbed open woodland (Van der Linden et al., 2005)

This assemblage is associated with most of the plains with gentle slopes. Soil depth varies from 150 to $300 \mathrm{~mm}$ (Table 2). In contrast to lithophyllic-woodland (3.1) soils, the diverse soil types of this habitat have a higher $\mathrm{K}$, lower $\mathrm{Zn}$ and lower carbon content (Table 3). The assemblage covers the largest part of the study area, most of which was previously cultivated.

There are no diagnostic species but distinguishing species include the shrubs Carissa macrocarpa and Rhoicissus tridentata (a climber) (species groups E and F; Table 1). As with the lithophyllic woodland (3.1), microphyllous species are the most dominant in the assemblage (species group H; Table 1). Conspicuous broadleaf-tree species that occur in the assemblage include Euclea racemosa, Olea europaea, Rhus rehmanniana and Phoenix reclinata (a palm) (species groups E, F and G; Table 1). Alien invaders are common and the presence of Chromolaena odorata indicates that it is spreading from the drainage lines into the drier parts of the study area.

The high densities of microphyllous species such as Acacia robusta, broadleaf species such as Gymnosporia senegalensis and invader species such as Psidium guajava in the lower 0,5 to $1,5 \mathrm{~m}$ classes may not be new recruits but plants maintained at this height by repeated fire in the past (Fig. $6 a, b, c)$. In addition, the alien invaders Schinus terebinthifolius and Chromolaena odorata and the indigenous shrubs Euclea racemosa and Scutia myrtina occur at high densities in the 1,5 to $3 \mathrm{~m}$ size class. An increase in woody-plant cover and a decrease in fire intensity and grazing in this habitat have been recorded during the last decade (Van der Linden et al., 2005). This suggests that suppressed tree seedlings are escaping the fire trap; it also suggests grazing disturbance. In time, this will result in a complete change in vegetation structure as was the case with the scrub forest (2), which changed from open savanna in the 1960s to forest in the 1990s (Van der Linden, 2004).

4. Acacia nilotica-Dichrostachys cinerea open woodland

= Heteropogon contortus-Tephrosia bachmannii grassland (Van der Linden et al., 2005)

This woody assemblage (Fig. 3) occurs in grassland at the highest altitudes (from 78 to $94 \mathrm{~m}$ ) (Table 2). In this habitat, the Mayo soil form is dominant and shallow (from 130 to $150 \mathrm{~mm}$ 


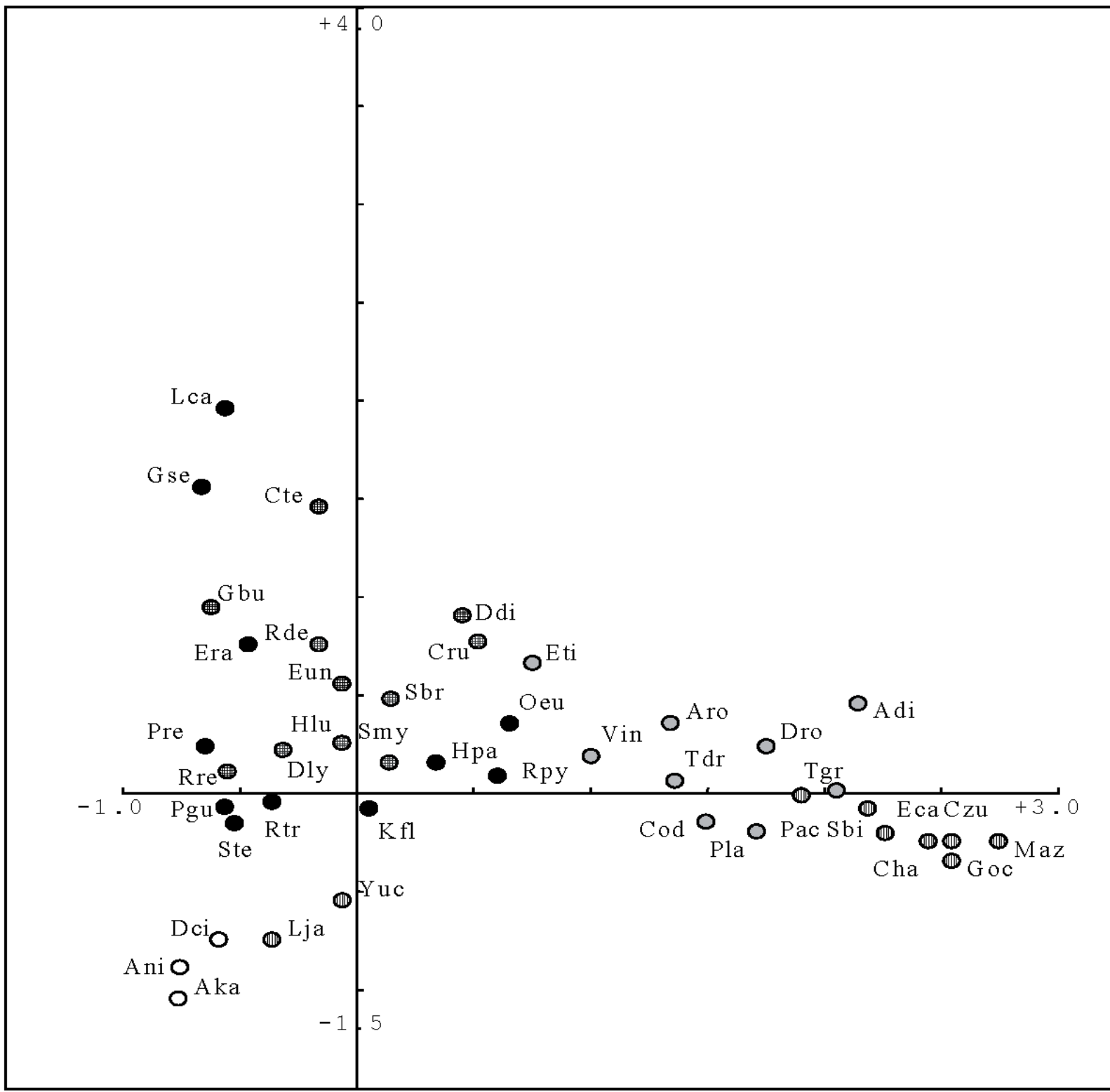

Drier, disturbed areas

$7-10^{\circ}$

Old fields

Overgrazed

Frequently bumt in the 1960's

$130-220 \mathrm{~mm}$

$20-45 \%$
Slope

Cultivation

Grazing

Fire

Soil depth

Canopy cover
Relatively undisturbed, closer to drainage lines

Up to $22^{\circ}$

No cultivation history

Not frequently grazed

No fire history

350-600mm

$90-95 \%$

Adi $=$ Apodytes dimidiata, Aka $=$ Acacia karroo, Ani $=$ Acacia nilotica, Aro $=$ Acacia robusta, Cha $=$ Commiphora harveyi, Cod $=$

Chromolaena odorata, Cte = Carissa macrocarpa $\mathrm{Cru}=$ Coddia rudis, Czuchys cinerea,

Ddi = Diospyros dichrophylla, Dly $=$ Diospyros lycioides, Dro = Dombeya rotundifolia, Eca = Erythrina caffra, Era $=$ Euclea

racemosa, Eti = Euphorbia tirucalli, Eun = Euclea undulata, Gbu = Gymnosporia buxifolia, Goc = Grewia occidentallis, Gse =

camara, Lia = Lippia javanica, Maz = Melia azederach, Oeu = Olea europaea, $\mathrm{Pac}=$ Pisonia aculeata, Pgu $=$ Psidium guajava,

$\mathrm{Pla}=$ Pavetta lanceolata, Pre $=$ Phoenix reclinata, $\mathrm{Rde}=$ Rhus dentata, $\mathrm{Rpy}=$ Rhus pyroides, $\mathrm{Rre}=$ Rhus rehmanniana, $\mathrm{Rtr}=$

Rhoicissus tridentata, $\mathrm{Sbi}=$ Sclerocarya birrea, $\mathrm{Sbr}=$ Schotia brachypetala, Smy = Scutia myrtina, Ste = Schinus terebinthifolius,

$\mathrm{Tdr}=$ Trichilia dregeana, Tgr = Trimeria grandifolia, Vin = Vangueria infausta, Yuc = Yucca gloriosa

- 1. Commiphora harveyi-Cussonia zuluensis riparian thicket

2. Trimeria grandiflora-Acacia robusta scrub forest

3.1 Euclea undulata-Rhus rehmanniana lithophyllic woodland

32 Euclea racemosa-Schinus terebinthifolius disturbed woodland

4.1 Acacia karroo-Acacia nilotica pioneer woodland

4.2 Acacia karroo-Lippia javanica wooded grassland

FIGURE 7

$\mathrm{CA}$ ordination depicting the distribution of species in areas with no disturbance closer to drainage lines and disturbed areas of drylands. Eigen values for axes one and two are 0,558 and 0,308 respectively, representing cumulatively $34,6 \%$ of total variance. 
deep) (Table 2). Soil erosion is extensive. Clay content is as high as $69 \%$ (Table 3). The assemblage is characteristic of areas with a history of uncontrolled fire and extensive over-grazing.

Trees are scarce in this "false" grassland but, according to aerial photographs, a clear and steady encroachment of woody species into the grassland has taken place over the past 75 years (Van der Linden, 2004). In line with its stronger affinity with the grassland biome, this assemblage has relatively low tree species-richness (Table 2) and is especially species-poor in the upper $(>3 \mathrm{~m}$ ) height class. A high density of microphyllous species of the lower size class (from 0,5 to $1,5 \mathrm{~m}$ ) is found because of frequent fires and over-grazing (Fig. 6b). An abundance of broadleaved and alien invader species is low for this assemblage (Fig. 6a, c). The canopy cover of the assemblage is lower than that of the other woody assemblages (namely the riparian thicket [1], scrub forest [2] and semi-closed woodland [3]) and lies between 5 and 40\% (Table 2).

No species are diagnostic for this assemblage but dominant taxa include Acacia karroo, A. nilotica, Dichrostachys cinerea, Lantana camara, Lippia javanica and Psidium guajava (species groups E and $\mathrm{H}$; Table 1), all of which occur mostly as shrubs due to frequent fires and heavy browsing. The taller individuals of microphyllous species usually occur in groups (bush clumps).

The open woodland is divided into two smaller sub-units based on altitude and tree density.

\subsection{Acacia nilotica-Acacia karroo pioneer woodland}

This assemblage is found in soil with a depth of approximately $200 \mathrm{~mm}$ (Table 2) in the drier parts of the study area. The soils contain very low Ca levels (1881 ppm, on average, for all three sample depths) when compared to the rest of the study area and especially to that of the riparian thicket (4788 ppm) (Table 3). The soils contain some of the highest levels of $\mathrm{K}$ in the study area (Table 3). This relatively flat area on the plateau has a history of extensive uncontrolled burning and over-grazing.

There are no diagnostic species for this assemblage but the assemblage does contain a high density of the broadleaved species Gymnosporia senegalensis, Rhus rehmanniana and Lippia javanica (species groups $\mathrm{G}$ and $\mathrm{H}$; Table 1). Typical for the study area, the highest density of woody plants comprises microphyllous species in the 1,5 to $3 \mathrm{~m}$ height class (Fig. $6 \mathrm{~b}$ ), namely Acacia karroo, A. nilotica and Dichrostachys cinerea (species group H; Table 1). The high density of microphyllous species in the 1,5 to $3 \mathrm{~m}$ and 0,5 to $1,5 \mathrm{~m}$ classes indicates that encroachment by microphyllous species is advanced, since the $>3 \mathrm{~m}$ height class was already dominated by microphyllous species.

A high density of juvenile invasive aliens in the 0,5 to $1,5 \mathrm{~m}$ height class holds a potential threat (Fig. 6c). These taxa and the microphyllous species are currently common in the lower height classes as a result of frequent fire. Fire exclusion could therefore lead to potential large-scale encroachment and/or invasion. It therefore seems as if this assemblage represents a seral stage of grassland undergoing early succession to becoming thornveld and, if unchecked, invaded.

\subsection{Acacia karroo-Lippia javanica wooded grassland}

This assemblage occurs mostly in the driest parts of the study area. Most of the area is relatively flat but it is associated with steep foot slopes in the surrounding hills. Soils are relatively shallow, varying from 100 to $150 \mathrm{~mm}$ in depth (Table 2). These soils and those of the riparian thicket (1) have the highest $\mathrm{Mg}$ content in the study area (Table 3). The soils have low nutrient levels; this is, however, expected of rocky areas.
The assemblage contains no diagnostic tree species but is dominated solely by microphyllous species similar to those in the pioneer woodland (4.1). It has the lowest tree density of all the assemblages in the study area (Fig. 6a, b, c). Four other dominant tree species are recorded for this assemblage, namely the invasive aliens Lantana camara and Psidium guajava (species group E; Table 1), Euclea racemosa and Lippia javanica (species groups $\mathrm{F}$ and $\mathrm{H}$; Table 1). Yucca gloriosa is common in this woody assemblage but is omitted from the analysis, as it is planted as living hedges and does not disperse naturally.

The assemblage has the lowest density of tree species in the $>3 \mathrm{~m}$ class ( 65 individuals) in the study area (Fig. $6 \mathrm{~b}$ ). Its highest density lies in the 0,5 to $1,5 \mathrm{~m}$ class, which comprises microphyllous species (Fig. 6b). Signs of invasion by Acacia karroo and Dichrostachys cinerea are apparent in the 0,5 to $1,5 \mathrm{~m}$ height class. This high density is thought to be a result of frequent fires, which restrict tree seedlings from developing into the upper height classes.

\section{Ordination of woody-plant assemblages}

The gradient of species assemblages is characterised at its extreme by the presence of broadleaved species such as Cussonia zuluensis, Erythrina caffra, Grewia occidentalis, Trichilia dregeana and Trimeria grandiflora in the closed coastal thornveld and their absence in the open coastal thornveld (Table 1). The tree species Gymnosporia buxifolia and Phoenix reclinata and the invader species Lantana camara, Psidium guajava and Schinus terebinthifolius occur frequently in the open coastal thornveld but are absent from the closed coastal thornveld (Table 1). Another important difference noted by Van der Linden et al. (2005) is the paucity of grasses in the closed coastal thornveld due to higher tree density and cover.

It is evident from available data that the distribution of species across the study area (Table 1) is not restricted to floristically distinct groups but rather to a gradient of species assemblages from open savanna woodland to scrub forest. To clarify this gradient, ordinations were used to plot woody assemblages along multi-dimensional axes on the basis of species composition and environmental data. The resultant diagrams show an arrangement of points along the axes in such a way that clustered points are similar in composition and scattered points are dissimilar in composition.

The environmental variables along the gradient that best explain the spread in species along the first axis of the CA (Fig. 7) include slope, cultivation, fire damage, grazing, soil depth and canopy cover. The riparian thicket (1) and scrub forest (2) are represented along the first axis and support a high diversity of broadleaf species (Fig. 7). The riparian thicket (1) does, however, consist of a denser, closed tree canopy with deeper soils where tree density and species-richness are much higher. Assemblages of the scrub forest (2) occur in moister, deeper and cooler soils lower down on the slopes near drainage lines along the Nseleni and Cwaka Rivers. Woody assemblages of the riparian zone are part of the oldest woody communities in the study area; they had no or little past disturbance through fire or grazing. These riparian assemblages occur in later stages of succession and with high species-richness, density and cover (Tables 1 and 2).

A second axis (Fig. 7) supports the transitional area on a level landscape that was previously cultivated, over-grazed and frequently burnt during the early 1960s. It has a lower diversity of broadleaved species. This habitat supports the woody assemblages of the semi-closed woodland (3) and open woodland (4). The ordination groups the woody assemblages of drier areas with higher disturbance factors (such as fire, over-grazing and previously cultivated land) as the pioneer woodland (4.1). This woody assemblage is relatively species- 


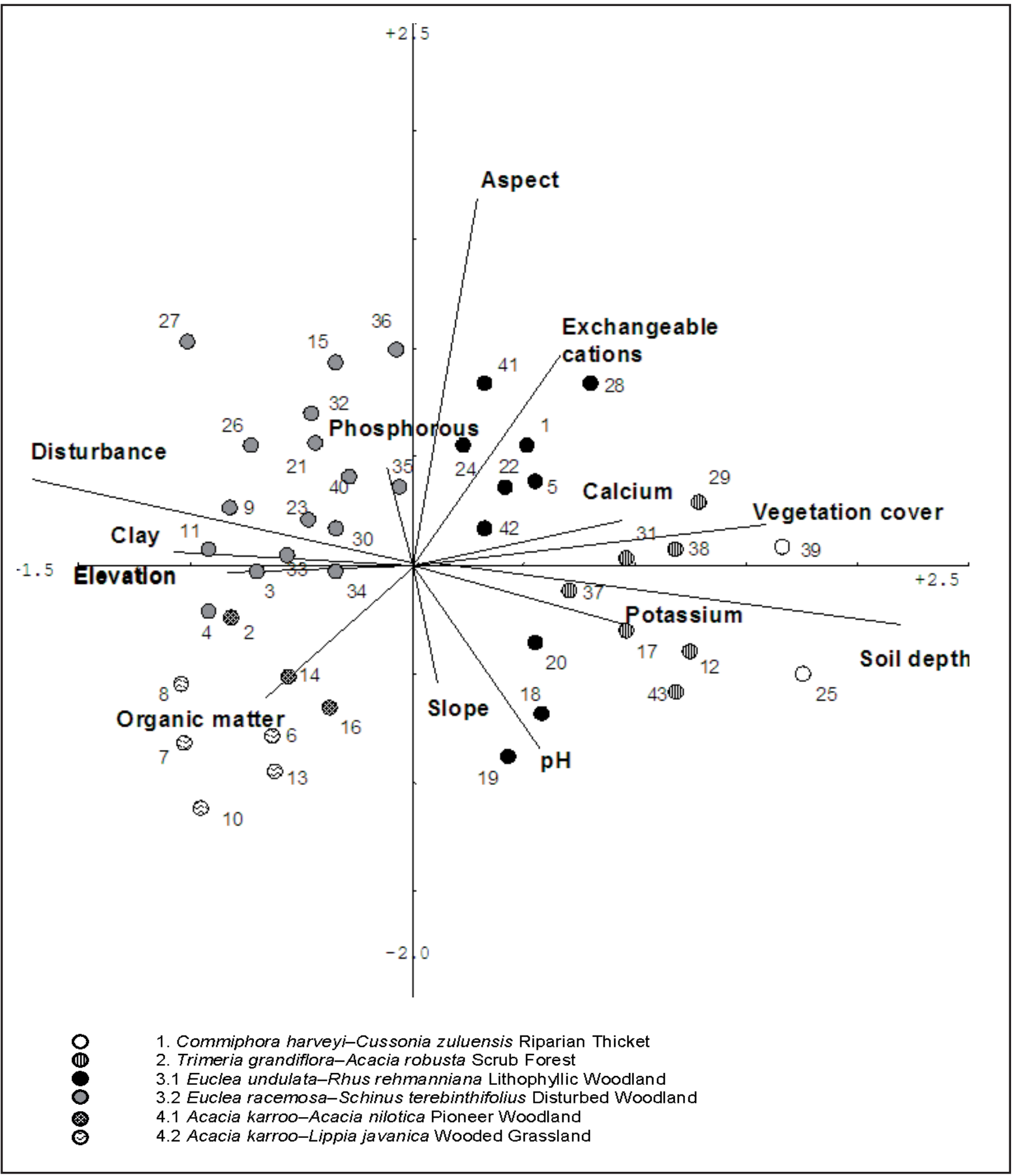

FIGURE 8

First axis of a CCA showing a gradient from lower-lying, relatively undisturbed, steeper areas with relatively deeper soils near drainage lines and a higher canopy cover to higher-lying, relatively flat areas with shallower soils and higher disturbance regimes. Axis one: woody species data; axis two: sites and aspect, elevation, slope, vegetation cover, disturbance, soil depth, and soil factors: calcium, phosphorus and potassium content, clay and organic-matter percentage, exchangeable cations and $\mathrm{pH}$

poor; it has low density and is dominated by microphyllous taxa (Table 2; Fig. 6). The more pristine wooded grassland (4.2), in deeper soil, is richer in herbaceous species than the pioneer woodland (4.1) due to the paucity of disturbance for longer periods (Van der Linden et al., 2005).

The CA (Fig. 7) explains much of the variation in the vegetation types. This corresponds well with the TWINSPAN classification (Fig. 3; Table 1). Floristic-environmental patterns, however, are better indicated in a two-dimensional plot of the axes of a CCA. Soil depth and disturbance are the most important variables on axis 1 , whereas aspect is the most important factor on axis 2 (Fig. 8). The first axis of a CCA (Fig. 8) corresponds with the CA (Fig. 7), namely a gradient from relatively undisturbed, lowlying areas with relatively deeper, less clayey soils near drainage lines and higher densities of broadleaf species to higher-lying areas with relatively shallower, clay soils that vary from 100 to $250 \mathrm{~mm}$ in depth and that were previously disturbed (Table 2). 
The second axis has a less pronounced gradient, from less steep areas dominated by the wooded grassland (4.2) and disturbed woodland (3.2) to more steeply sloped areas characterised by the assemblages of the lithophyllic woodland (3.1) only. Nutrient levels vary with specific habitat types: high Ca content correlates with the riparian-thicket (1) assemblages and high $\mathrm{K}$ levels correlate with the scrub forest (2) assemblages (Fig. 8; Table 3).

\section{Structural history of woody-plant assemblages}

The structural history at OSCA follows a common trend of vegetation change in South Africa, namely the conversion of open savanna to closed savanna through the invasion of microphyllous woody plants, Acacia species in particular (Smit, 2004). A change in the species composition of the plant communities at OSCA, especially of the species-poor communities of former cultivated and disturbed areas, is evident when woody assemblages are considered. The vegetation of older, broadleaved bush clumps and under-utilised areas near drainage lines in the study area is species-rich. This supports what Le Roux (1996) finds regarding the rate and patterns of woody-cluster development. It can therefore be expected that, over time, more broadleaved species could find their way into other parts of the area, depending on the management of the farm. The result could be complete vegetation change from grassland to closed woodland due to favourable climate change.

In addition, species-richness between previously cultivated and pristine sites differs, the latter containing higher species frequency. Previous human disturbance, such as cultivation, plays a role in the floristic composition of some plant communities, since previously cultivated sites support common species, namely Acacia karroo, A. nilotica and Dichrostachys cinerea, which thrive under a wide range of environmental conditions, including other types of disturbances, such as fire and over-grazing or under-utilisation.

In the first half of the previous century, frequent fires and probably prevailing climatic conditions contained woody species to mere remnants along riparian zones in the Zululand coastal thornveld. Aerial photographs taken between 1937 and 1996 show that lowland areas near drainage lines were the first to become wooded (Fig. 1a, b) and appear to be in a late seral stage of succession. It was only in the 1960s that earlier seral communities reappeared due to disturbance: over-grazing and less-frequent fires enhanced encroachment by providing source populations with favourable habitat that consistently experienced high seed production and by releasing numerous emigrants into other moist environments.

It is not possible to determine whether the riparian areas were previously dominated by Acacia species, although results suggest that the areas were indeed once Acacia woodlands, as many large, mature microphyllous species are still found in the riparian communities (Fig. 6b). This suggests that riparian areas reached a later seral stage of succession in contrast to the higher-lying areas, such as the pioneer woodland (4.1), which is still in the preliminary stages of succession. These vegetation changes are thought to be the result of changes in the prevalence of some of the previously mentioned disturbance factors.

Trollope, Trollope, Biggs, Pienaar \& Potgieter (1998) find that, in general, fire per se favours the development and maintenance of predominantly grassland vegetation by destroying juvenile trees and shrubs and preventing the development of more mature plants to a taller, more fire-resistant stage. This is also evident in OSCA plots where Acacia karroo, Dichrostachys cinerea and Gymnosporia senegalensis occur as small shrubs due to frequent fires. Once bush growth is dominant, however (this consequently suppresses grass growth), fire no longer has this effect because of insufficient grass-fuel load for intense fires, which corresponds to the previously discussed effect of fires on the grass-bush balance (Tainton \& Mentis, 1984; Trollope, 1984).

The study revealed that the spread of woody-plant species to the higher-lying areas due to poor veld management and a large seed pool has become a threat. Bush encroachment furthermore paves the way for invasion by the aggressive alien Chromolaena odorata by suppressing the growth of grasses under the canopy, which eventually prevents disturbances such as grazing or fire. This creates an ideal habitat for Chromolaena odorata to spread into these areas and dominate.

\section{CONCLUSION}

Past land-use practices and soil properties are the main factors determining floristic variation in the riparian woody assemblages of the Zululand coastal thornveld. These factors have a pronounced influence on composition, species-richness and the density of woody-plant communities, which is in agreement with the usual effects of edaphic conditions on woody composition and structure. This study shows that the local land use of "false" grassland has the effect of reversion to and the maintenance of the vegetation of earlier seral stages through bush clearing, over-grazing and fire. It is therefore inevitable that, in the absence of or, at the least, a decrease in the magnitude of these previously retarding influences, grassland has the potential of being completely colonised by woodland and forest communities.

The composition of woody-plant assemblages suggests that patterns of population change differ markedly among species or, for some species, among various plant communities. Populations of the most dominant species, Acacia karroo and $A$. nilotica, increase from the drier areas to the lower-lying areas, particularly on former cultivated lands, but numbers decrease in the wetter, lower-lying areas due to interspecific competition.

In summary, it must be stressed that the vegetation at OSCA is generally too far advanced to a later seral stage of closed woodland and forest to be reverted by factors that previously maintained early seral stages. Extensive management action is required until such time as fire and grazing can again assert themselves to maintain the delicate open/closed savanna equilibrium of the Zululand coastal thornveld, on the understanding that the effect of either Iron Age man or natural processes may always need to be simulated. Alternatively, the area could be allowed to progress undisturbed, allowing a unique opportunity for research into the dynamics of forest development.

The structure of plant communities (based on aerial photographs since 1937) corresponds with the view by Acocks (1988), who suggests that woody plants first seem to invade and occupy valleys, drainage lines and lower-lying areas near rivers before they progressively become established further up valley slopes and outwards from these drainage areas to drier areas. It is suggested that the open woodlands and open grasslands of the area were maintained by the combined influence of bush-clearing and tree-felling by early inhabitants as well as by cultivation, over-grazing and the introduction of frequent fires.

Successional stages are evident in the study area, with pioneer species modifying environmental influences and facilitating the establishment of later successional species. This has resulted in a progressive change in communities from open grasslands to thickets and from open woodlands of microphyllous, shadeintolerant, fire-tolerant species to closed woodland, shadetolerant and fire-intolerant species. This supports the decision by Mucina and Rutherford (2006) to classify the Zululand 
coastal thornveld under the lowveld savanna bioregion instead of the sub-escarpment grassland bioregion.

If South Africa's natural resources are not well managed and protected according to ecologically sound management plans, sustainable utilisation and conservation will not be achieved (Pierce, Cowling, Knight, Lombard, Rouget \& Wolf, 2005). The results of vegetation change and habitat features derived from this study should enable the management of the area to be scientifically and ecologically sound and - hopefully encourage further studies on this rare and endemic vegetation unit. Future research should focus on methods to quantify disturbance, such as fire history and old fields, with the aid of digitised aerial photographs and/or satelite imagery.

\section{ACKNOWLEDGEMENTS}

OSCA and the University of Zululand financially supported this research. Mr Craig Morris from the Agricultural Research Council is thanked for valuable assistance with data analysis. Agromet kindly supplied climate data. The Soil Fertility Service Section of the KwaZulu-Natal Department of Agriculture and Environment Affairs at Cedara conducted the soil analysis.

\section{REFERENCES}

Acocks, J.P.H. 1988. Veld types of South Africa. Memoirs of the Botanical Survey of South Africa, 57: 1-146.

AGROMET. 2002. Zululand climate report. Unpublished report. Pretoria: Institute for Soil, Climate and Water.

Breebaart, L., O'Connor, J.C., Morris, C.D. \& Rushworth, I.A. 2001. The effects of topo-edaphic variables and cultivation on the woody vegetation of Weenen Nature Reserve, KwaZulu-Natal. African Journal of Range and Forage Science, 18(2): 75-91.

Brown, K.A., Scatena, F.N. \& Gurevitch, J. 2006. Effects of an invasive tree on community structure and diversity in a tropical forest in Puerto Rico. Forest Ecology and Management, 226(1-3): 145-152.

Brown, L.R. \& Bredenkamp, G.J. 2004. The use of structural species size classes in the description of the woody vegetation of a nature reserve. African Journal of Ecology, 42(4): 252-269.

Camp, C. 1997. The bioresource groups of KwaZulu-Natal. Internal report N/A/97/6. Pietermaritzburg: Cedara Natural Resource Section.

Farina, M.P.W. 1981. The hunter system of soil analysis. Fertiliser Society of South Africa Journal, 1: 39-41.

Granger, E., Bredenkamp, G.J. \& Van Rooyen, N. 1996. Coastal bushveld-grassland, in: A.B. Low \& A.G. Rebelo (eds.). Vegetation of South Africa, Lesotho and Swaziland. Pretoria: Department of Environmental Affairs and Tourism, pp. 30-31.

Hill, M.O. 1979. TWINSPAN: A Fortran program for arranging multivariate data in an ordered two-way table by classification of individuals and attributes. New York: Cornell University, Ithaca.

Hunter, A. 1975. New techniques and equipment for routine soil plant analytical procedures in soil management in tropical America. Raleigh NC: NC State University.
Le Roux, I.G. 1996. Patterns and rate of woody vegetation cluster development in a semi-arid savanna, Natal, South Africa. MSc thesis, Pietermaritzburg: University of Natal.

Michalsky, J.J., Perez, R., Harrison, L. \& Le Baron, B.A. 1991. Spectral and temperature correlation of silicon photovoltaic solar radiation detectors. Solar Energy, 47: 299.

Mucina, L. \& Rutherford, M.C. 2006. The vegetation of South Africa, Lesotho and Swaziland. Strelitzia, 19: 748-790.

O'Connor, T.G. \& Crow, V.R.T. 2000. Rate and pattern of bush encroachment in Eastern Cape savanna and grassland. African Journal of Range and Forage Science, 16(1): 26-31.

Pierce, S.M., Cowling, R.M., Knight, A.T., Lombard, A.T., Rouget, M. \& Wolf, T. 2005. Systematic conservation planning products for land-use planning: Interpretation for implementation. Biological Conservation, 125(4): 441-458.

Rapport, D.J. \& Whitford, W.G. 1999. How ecosystems respond to stress: Common properties of arid and aquatic systems. BioScience, 49(3): 193-202.

Ringrose, S., Chipanshi, A.C., Matheson, W., Chanda, R., Motoma, L., Magole, I. \& Jellema, A. 2002. Climate and human-induced woody vegetation changes in Botswana and their implications for human adaptation. Environmental Management, 30(1): 98-109.

Siebert, S.J., Matthee, M. \& Van Wyk, A.E. 2003. Semi-arid savanna of the Potlake Nature Reserve and surrounding areas in Sekhukhuneland, South Africa. Koedoe, 46(1): 29-52.

Smit, G.N. 2004. An approach to tree thinning to structure southern African savannas for long-term restoration from bush encroachment. Journal of Environmental Management, 71(2): 179-191.

Soil Classification Work Group. 1977. Soil classification: A taxonomic system for South Africa. Pretoria: Department of Agricultural Development.

Tainton, N.M. \& Mentis, M.T. 1984. Fire in grassland, in: P. de V. Booysen \& N.M. Tainton (eds.). Ecological effects of fire in South African ecosystems. New York: Springer Verlag, pp. 15-147.

Ter Braak, C.J.F. \& Smilauer. P. 2002. CANOCO reference manual and CanoDraw for Window's user's guide: Software for canonical community ordination (version 4.5). New York: Ithaca.

Trollope, W.S.W. 1984. Fire in savanna, in: P. de V. Booysen \& N.M. Tainton (eds.). Ecological effects of fire in South African ecosystems. New York: Springer Verlag, pp. 149-175.

Trollope, W.S.W., Trollope, L.A., Biggs, H.C., Pienaar, D. \& Potgieter, A.L.F. 1998. Long-term changes in the woody vegetation of the Kruger National Park, with special reference to the effects of elephants and fire. Koedoe, 41(2): $103-112$.

Van der Linden, J.P. 2004. Vegetation analysis of Owen Sitole Agricultural College campus, KwaZulu-Natal, South Africa. MSc thesis, KwaDlangezwa: University of Zululand.

Van der Linden, J.P., Siebert, S.J., Siebert, F., Ferreira, D.P. \& Bredenkamp, G.J. 2005. Vegetation of the Owen Sitole College of Agriculture in Zululand, KwaZulu-Natal. Koedoe, 48(1): 33-56.

Visser, D.J.L., Coertze, F.J. \& Walraven, F. 1989. Explanation of the 1:1 000000 geological map, fourth edition, 1984: The geology of the Republics of South Africa, Transkei, Bophuthatswana, Venda and Ciskei and the Kingdoms of Lesotho and Swaziland. Pretoria: Government Printer.

Westhoff, V. \& Van der Maarel, E. 1978. The Braun-Blanquet approach, in: R.H. Whittaker (ed.). Classification of plant communities. The Hague: Junk. 